\title{
O pewnym chłopskim geście. Od rabacji do Zagłady
}

Agnieszka Dauksza 


\section{O pewnym chłopskim geście. Od rabacji do Zagłady}

Agnieszka Dauksza

TEKSTY DRUGIE 2017, NR 6, S. 95-106

DOI: $10.18318 /$ td.2017.6.6

ak mówić i pisać o chłopach? Problem metodologiczny i etyczny towarzyszy chyba wszystkim, którzy z pozycji uniwersyteckiej szukają przejawów chłopskości w dawnej i współczesnej kulturze polskiej. No właśnie, słowa „szukamy przejawów chłopskości” zdradzają dwuznaczność tych praktyk. Choć - jak niby wiemy - my wszyscy z chłopów, na co dzień większość o tym nie pamięta lub nie chce pamiętać; także na poziomie deklaracji nie jest to z reguły istotna część naszego indywidualnego i wspólnotowego dziedzictwa tożsamościowego. Niechciana, odrzucona, zapomniana lub wyparta historia choć aktualna w naszych genach i mentalności - wciąż leży odłogiem. Tropienie tego dziedzictwa przypomina $\mathrm{w}$ istocie poszukiwanie skradzionego listu z opowiadania E.A. Poe... Rzecz w tym, że to my jesteśmy otwartymi listami, z naszymi bliskimi, krewnymi, przodkami, opowieściami rodzinnymi, wreszcie z naszymi ciałami rozumianymi jako materialne archiwa.
Agnieszka Dauksza dr, pracuje w Katedrze Antropologii Literatury i Badań Kulturowych WP UJ. Autorka książek: Afektywny modernizm. Nowoczesna literatura polska winterpretacji relacyjnej (2017), Klub Auschwitz i inne kluby. Rwane opowieści przeżywców (2016) i Kobiety na drodze. Doświadczenie przestrzeni publicznej w literaturze przełomu XIXiXX wieku (2013). 
Warto uświadomić sobie, że historia chłopska prawdopodobnie nigdy nie zostanie opisana. W każdym razie nie będzie to opowieść, którą zwykliśmy uznawać za historię przez wielkie „H”. Niedostatek przekazów oraz szlachecko-mieszczańskie i inteligenckie sprofilowanie archiwów nie jest chyba jedyną przeszkodą. Pozostaje bowiem zasadnicza kwestia identyfikacji i zapośredniczenia.

Jeśli można pokusić się o pewne uogólnienie, współczesne, akademickie zainteresowanie wsią i chłopami opiera się zwłaszcza na dwóch typach badań i typach badaczy: terenowcach, czyli "praktykach” wsi oraz „teoretykach” czy "filozofach" wsi. Tym pierwszym niekiedy zarzuca się, że ich ugruntowane w działaniu zaangażowanie w lokalne społeczności jest nadto zaangażowane i nadto lokalne, przez co trudno im przejść z poziomu konkretnych case studies do bardziej uniwersalnego poziomu opisu i wypracowania operacyjnych teorii. „Teoretykom” wsi wytyka się z kolei nadmierną ogólność refleksji, posługiwanie się uproszczonymi konstruktami, a nie faktami oraz korzystanie z abstrakcyjnych kategorii chłopskości i wiejskości, które nie znajdują żadnego uzasadnienia ani w historycznej, ani w obecnej sytuacji wsi.

Ponad tymi nurtami mnożą się jednak liczne pytania: czy o chłopach mogą pisać wyłącznie oni sami? Czy aby na pewno narracje pisane z pozycji miejskiej czy akademickiej reprezentują wieś? Czy chłopi polscy utożsamiają się z wizerunkami literackimi i filmowymi, które z perspektywy miejskiej uznajemy za emanację chłopskości? Być może - skoro obiekt tak bardzo i stale nam się wymyka - trzeba szukać alternatywnych ujęć, nowych metod, innych narzędzi opisu?

Powyższe naiwne pytania towarzyszą mi nieodmiennie, odkąd uświadomiłam sobie, jak trudno orzekać o chłopach, jeśli tylko faktycznie potraktujemy ich jako pełnoprawnych uczestników polskiej kultury i wspólnoty. W efekcie piszę o karkołomności przekroczenia własnej perspektywy poznawczej, a także o miejsko-wspólnotowym wyobrażeniu wiejskości. Zatem rzecz będzie o relacjach, podstawowej kompetencji ludzkiej, którą jest czytanie cudzych reakcji cielesnych, oraz o pewnym geście.

Kończąc ten „rozterkowy” wstęp, proponuję choćby pobieżną lekturę forów internetowych, które uznaję za przejaw myślenia lub odczuwania reprezentatywny dla jakiejś części polskiego społeczeństwa. Otóż powracającym wątkiem dyskusji poświęconych sprawom wsi jest rzezanie, podcinanie i podrzynanie gardła, które bywa wspominane w kontekście chłopsko-szlacheckim, rabacji galicyjskiej, rzezi wołyńskiej, w kontekście współczesnych stosunków polsko-ukraińskich, dzisiejszych migracji i emancypacji mieszkańców wsi, 
a także imigrantów z Bliskiego Wschodu i Afryki'. Zazwyczaj chodzi tyleż o drastyczne opisy zadawanej w ten sposób przemocy, ile o proste hasło czy obraz podcinania gardła, gest, który okazuje się kluczowym wyobrażeniem stanowiącym natychmiast rozpoznawalną metaforę napiętych relacji - historycznych, współczesnych lub antycypowanych. Poprzestanę na dosłownie kilku przykładach: „wieś już ma dość takiego życia w biedzie. Najchętniej by nam miastowym podcięli głowy jak swoim zwierzętom i przyszli na nasze miejsce", , jak wsioki ze wschodu nam rzezały gardła i mordowali to z nimi zrobiliśmy porządek, trzeba się wziąć za ciapatych. Od czego jest Polska Husaria”, ,najpierw rabacja, teraz islamizacja. Efekt zapraszania islamistów do nas to nasza dekapitacja”, ,ten mały islamista nie robi niewinnego gestu. Już tak kiedyś pokazywali sobie i z tego była rzeź galicyjska i rzeź wołyńska"2.

Nie ulega wątpliwości, że w wypowiedziach mieszają się w przedziwnej logice ignorancja, niewiedza historyczna, ksenofobia, rasizm, wątek klasowy, poczucie wyższości i jednocześnie resentyment oraz lęk przed bliżej nieokreślonym, zewnętrznym zagrożeniem, które mogłoby naruszyć status quo. Spoiwem okazuje się właśnie gest i wyobrażenie tej czynności - minionej, dokonanej i potencjalnej - przypisywanej woli współczesnych chłopów i migrantów. Przyjdzie jeszcze rozważyć przyczyny tego skojarzenia aktantów. Tymczasem stawiam pytanie, czy i dlaczego w obiegowej opinii gest rzezania jest kojarzony z chłopskością? I czy rzeczywiście można go uznawać za emblemat chłopa? Z pewnością jest to stereotyp, jednak interesujące jest jego niejednoznaczne oddziaływanie.

Z perspektywy semantycznych badań nad teorią komunikacji - np. prowadzonych przez Jolantę Antas - gest podrzynania uznawany jest za sygnał kodowany o "najmniejszym dystansie między kodem a opisywanym przedmiotem lub zjawiskiem”, a „użyty sposób kodowania jest w istocie tożsamy z przedmiotem podlegającym kodowaniu"3. W przypadku ikonicznego gestu podcinania gardła kod nie tyle przypomina czynność, ile faktycznie nią jest ${ }^{4}$. Gest może być wówczas tożsamy z groźbą. Takie myślenie zbiega się z intuicją

1 Mam świadomość, że wątek etniczny, np. ukraińskich chłopów, jest problemem ważnym i złożonym, ale jednak osobnym, m.in. przez skomplikowanie zaszłości historycznych, dlatego nie podejmuję się tutaj jego analizy.

2 Wypowiedzi anonimowych osób (często niepodpisanych nawet pseudonimem) pochodzą z forów portali Wyborcza.pl, Niezależna.pl i YouTube.

3 J. Antas Semantyczność ciała. Gesty jako znaki myślenia, Primum Verbum, Łódź 2013, s. 45-46.

4 Tamże. 
José Ortegi y Gasseta, przekonującego, że to właśnie w gestach należy szukać korzeni języka, gdyż przekazywane przez nas znaki dźwiękowe wywodzą się z gestykulacji ciała i wciąż znajdują w niej odzwierciedlenie ${ }^{5}$.

Jednakże rozpoznanie gestu rzezania jako formy dzielenia przemocy, choć trafne, nie jest wystarczające. Proponuję więc jeszcze inny typ namysłu, mianowicie potraktowaniegestu jako znaczącego nośnika pamięci kulturowej oraz przekaźnika energii społecznej. Nie traktuję go jako psychoanalitycznego symptomu jednostki, ale jako cielesną lub wyobrażeniową formę reprezentacji afektu, odczuwania i myślenia wspólnoty. W praktyce nie będę w gruncie rzeczy orzekać ani o chłopach, ani o panach, ale o relacjach klasowych i społeczno-politycznym uwikłaniu.

Rozważając powtarzalne funkcje gestów, zwracam uwagę zwłaszcza na cztery aspekty: ujawnienie poprzez gest afektu, komunikat zawarty w geście, metaforyczność tej czynności, ikoniczność lub metonimiczność gestu, a także jego sprawczość. Gdy znane z tekstów kultury lub codziennego życia społecznego gesty podrzynania gardła rozkłada się na „części pierwsze” i zarazem rozważa się je w szerszym kontekście sytuacyjnym, okazuje się, że bywają wyrazem gniewu, bezsilności, interpasywności, braku sprawczości i/lub niemocy faktycznego działania. Jednocześnie są one informacją o niezgodzie na stan rzeczy, sprzeciwem wobec niesprawiedliwości pozycji. Ten ikoniczny gest jest też symbolicznym aktem przemocy, metaforą czy wizualizacją fizycznej anihilacji tego, wobec kogo jest wykonywany. Aspekt performatywnej sprawczości realizuje się właśnie w relacyjności tego gestu, gdy jeden prosty ruch ręki wytwarza duży ładunek napięcia, ukazuje i zarazem uruchamia nadwyżkę energii, w dziwny, najczęściej antagonistyczny sposób spajając jednostki lub grupy, jakieś , ja” i „ty” lub jakieś „my” i „wy”. Gest podrzynania jest bowiem zawsze wobec kogoś, wikła drugą stronę, wywołuje ją i angażuje, tym bardziej że jego ikoniczność jest formą groźby czy zapowiedzią fizycznej przemocy, niekoniecznie jednostkowej, lecz często ewokującej mobilizację szerszej grupy „swoich” o zbliżonej identyfikacji.

Nie ulega wątpliwości, że studia gestyczne to projekt na przyszłość. Pytanie jednak, jak tymczasem pozyskać analizę gestu dla badań nad chłopskością? Można wykorzystywać opisy literackie, kroniki i świadectwa jako rezerwuar przypadków, w których mowa gestów ukazuje w nieco innym świetle dynamikę relacji społecznych. Zapewne warto także potraktować gesty

5 J. Ortega y Gasset Dehumanizacja sztuki i inne eseje, Muza, przeł. P. Niklewicz, Warszawa 1980, s. 394-397. 
jako źródło komplementarne dla materiałów pisanych i analizować pod tym kątem przekazy wizualne, obrazy, rzeźby, rękodzieło, taniec i wszelkie inne praktyki rytualne.

Konieczna jest refleksja nad pojedynczymi reprezentacjami, gdyż gest ma to do siebie, że rozpatrywany teoretycznie przynosi niewielkie pożytki, a dopiero jego aktywowanie w konkretnym kontekście pozwala aktualizować wirtualne aspekty. Skupię się pokrótce na dwóch przypadkach odwołujących się do nietożsamych porządków i zdarzeń historycznych - pierwszym będzie film Niepamięć Pawła Brożka, drugim Shoah Claude’a Lanzmanna.

\section{Przypadek 1.}

Zrealizowany przez Stowarzyszenie Folkowisko dokument Niepamięć (2015) miał być wedle założenia twórców „pierwszym filmem o dziedzictwie pańszczyzny". Dwoje młodych bohaterów, Magdalena Bartecka i Franciszek Ledóchowski, dociekając losów swoich rodzin, jednocześnie porównuje własne doświadczenia z dzieciństwa, wychowanie, kompetencje i perspektywy:

ta dwójka odbywa refleksyjno-emocjonalną podróż na lubelską i podkarpacką wieś, gdzie w zmierzeniu się z własną przeszłością pomagają im spotkania z innymi uczestnikami popańszczyźnianego dramatu: wiejskimi gospodarzami, bartnikiem oraz wiekowym hrabią. Czy potomkini ciemiężonych chłopów pańszczyźnianych i potomek arystokratycznych elit nawiążą nić porozumienia? Czy pojednanie między nimi jest możliwe?

Problem dziedzictwa pańszczyzny i jego oddziaływania na współczesną wspólnotę domaga się osobnego namysłu, także w kontekście dokumentu Niepamięć. Tymczasem jednak warto rozpatrzeć jeden detal, mianowicie gest. Istotna jest przede wszystkim scena, w której 88-letni Bartecki, dziadek głównej bohaterki-chłopki, ochoczo opowiada o przedwojennym marzeniu lokalnych chłopów, którzy „schodzili się i rozmawiali”, by „rzezać panów, rzezać panów. Księży i panów rzezać” [30:35], po czym stwierdza: „ale wymarli dziś te wszystkie rzezaki, wymarli, nie mogą głosić takiej polityki” [30:58]. W tym momencie Ledóchowski pyta: „Co to znaczy rzezać?”, na co starszy

6 Opis filmu dostępny pod adresem: http://folkowisko.gorajec.info/film-dokumentalny/ (21.01.2017). 
mężczyzna odpowiada ruchem ręki, przeciągając nią po szyi, i dopowiada: „zarezywać, zarżnąć, takie to było”. Kamerzysta pyta Ledóchowskiego: "Co, przestraszyłeś się trochę?", a ten odpowiada: „Tak”, zasłania dłonią usta i śmieje się nerwowo. Bartecki ze smutkiem dopowiada: „Taka była bieda, panie. I rolnik nie był poważany. Rolnik był... jak to nazwać - niczym" [31:31]. Ewidentnie gest funkcjonuje tu jako relikt, emblemat minionych relacji społecznych, pamiętany przez chłopów, lecz wygasły, nietraktowany już jako realna groźba wyrównania sił. Skądinąd okazuje się, że takie wspomnieniowe odegranie gestu może jednak poruszać, niepokoić czy wręcz napawać strachem drugą stronę - w tym przypadku potomka "panów" Ledóchowskich.

W jednej z kolejnych scen Franciszek Ledóchowski rozmawia z ojcem Magdaleny Barteckiej: „Co pan myśli o pańszczyźnie?”., Nie wiem. Nie mogę się wypowiadać" - pada odpowiedź i dopiero gdy Ledóchowski przedstawia się jako dziedzic hrabiowski, ojciec Bartecki ze śmiechem mówi: „panoszczyki”, i kontynuuje: „Przychodził tu taki kuzyn, starszy już, Bolek, i mówił: o, ten pan był dobry, to go wolniutko rżnijcie [gest cięcia], bo to dobry pan był". Barteccy śmieją się, a Ledóchowski patrzy na nich zasępiony i mówi: „Rozumiem, że pan to opowiada jako ciekawostkę? Przecież nikogo by pan piłą nie rżnął? Żyjemy w takich czasach, że nie ma różnic, np. między mną i Magdą”. Bartecka odpowiada: „Właśnie są różnice, nawet w gestach”. Konsekwentnie w różnych momentach filmu bohaterowie zwracają uwagę na własne odmienne zachowania przy stole, różne odruchy i nawyki zdradzające nietożsame kompetencje i doświadczenia. Widz czuje się nieswojo, śledząc faktyczne i potencjalne rozbieżności. Jednak być może warto przekroczyć zawstydzenie czy zażenowanie i spojrzeć na różnice nie jako marginalne czy zbędne pochodne komunikacji, ale jako pełnoprawne, znaczące sygnały. Tym bardziej że gesty ewidentnie są przez bohaterów „używane” jako argumenty w sprawie.

\section{Przypadek 2.}

Podejmę się w tym miejscu refleksji nad jedną, pamiętną sceną z Shoah Claude'a Lanzmanna. Około osiemdziesiątej minuty filmu rozpoczyna się ponad 5-minutowa sekwencja niemal w całości poświęcona gestowi podcinania gardła. Najpierw jest on kilkukrotnie wykonywany w grupie okolicznych chłopów wspominających żydowskie transporty wiezione na eksterminację do Treblinki. Następnie gest jest przedmiotem rozmowy z Czesławem 
Borowym, który ponawia go, opowiadając o dziesiątkach mijających go pociąów i tysiącach Żydów, których odprowadzał wzrokiem i właśnie gestem podrzynania wykonywanym pod nieuwagę nazistowskiej eskorty, by - jak twierdzi - ostrzec Żydów o czekającej ich śmierci. Filmowy kontekst wypowiedzi przywodzi na myśl różne znaczenia słowa gest - jako intencjonalnego ruchu, środka wyrazu scenicznego, ale i wspaniałomyślnego czynu, jakim miała być dla Borowego owa przestroga.

Przywołane sceny trwale wpisały się w pamięć o kontrowersyjnym obrazie Lanzmanna - do tego stopnia, że gdy w Liście Schindlera Stevena Spielberga pojawiła się scena, w której dziecko wykonywało gest podcinania gardła, kilkoro amerykańskich badaczy oskarżyło Spielberga o splagiatowanie filmu Lanzmanna... ' Gesty z Shoah doczekały się szeregu komentarzy, zwłaszcza w zachodniej i izraelskiej krytyce. Oceniane są jednoznacznie negatywnie, wbrew literalnym zapewnieniom polskich chłopów przekonujących o słusznych zamiarach i gestowej przestrodze kierowanej pod adresem Żydów. Mowa jest często o towarzyszącym gestowi diabolicznym uśmiechu, który ma zdradzać prawdziwe uczucia i intencje Polaków ${ }^{8}$. Także Lanzmann wprost stwierdza "niepokojąco sadystyczny" charakter chłopów czerpiących "rozkosz" z cudzego cierpienia9. Choć nie zawsze jest to ewidentne podczas filmowej interakcji reżysera z chłopami, w której widać raczej jego szydercze rozbawienie i politowanie, późniejsze autorskie komentarze wskazują, że Lanzmann żywi wstręt i pogardę do swoich rozmówców, których traktuje jako obłudnych, nieczułych i współwinnych zbrodni ${ }^{10}$. Nie trzeba dopowiadać, że w tym układzie film jawi się reżyserowi jako proces sądowy, a on sam występuje w roli świadka, oskarżyciela i sędzi, który sprytem i odpowiednim montażem obnaża winy zapisane w chłopskich ciałach i umysłach. Problem jednak w tym, że choć trudno obrazowi Lanzmanna odmówić fundamentalnego znaczenia faktograficznego i estetycznego, omawiane sceny wcale nie są jednoznaczne i można pokusić się o nieco inne odczytanie. Zwłaszcza jeśli odniesie się je do tzw. ścinków, czyli ponad 250 godzin wywiadów, które nie

7 Por. np. B. Cheyette The Uncertain Certainty of Schindler's List, w: Spielberg's Holocaust: Critical Perspectives on Schindler's List, ed. Y. Loshitzky, Indiana University Press, Bloomington 1997, S. 191.

8 Por. D. LaCapra History and Memory After Auschwitz, Cornell University Press, Ithaca-London 1998, s. 125 .

9 C. Lanzmann Zając z Patagonii, przeł. M. Ochab, Wydawnictwo Czarne, Wołowiec 2010. 
weszły do ostatecznej wersji filmu, a które zostały niedawno udostępnione przez muzeum w Waszyngtonie" ${ }^{11}$.

Po pierwsze, okazuje się, że „diaboliczny” śmiech i gest Borowego, który znamy z filmu, był przez Lanzmanna cierpliwie prowokowany. W ścinkach znajdujemy ponad godzinny materiał wywiadu, z którego niemal 30 minut poświęcone jest dopytywaniu reżysera o gest podrzynania gardła. Lanzmann kilkanaście razy na różne sposoby naprowadza na ten gest, śmieje się, przeciąga ręką po szyi, próbując rozbawić i ośmielić rozmówcę. Borowy ze zdumiewającym spokojem nieodmiennie odpowiada, że była to według niego jedyna dostępna metoda, by błyskawicznie, niepostrzeżenie dla okupanta informować Żydów o zagrożeniu. W kluczowym momencie Lanzmann zmienia taktykę i zwraca się przez tłumaczkę: „Pan [Lanzmann] mówi, że ten gest... że tak to raczej świnię się zarzyna, prawda?” [7:20]. „No tak” - odpowiada spokojnie Borowy, patrząc wprost w oczy reżysera.

Właściwie trudno w tych licznych, długich, ścinkowych dialogach rozpoznać rubasznego, cwaniackiego Borowego znanego z o wiele krótszych ujęć filmowych. Choć ta antypatyczna postać nigdy nie wzbudza zaufania, sympatii czy współczucia odbiorcy, tym razem trzeba przyznać, że ewidentnie nie ma w jego postawie i wypowiedziach niczego cynicznego czy diabolicznego. Jest pewny siebie, logicznie argumentuje, bywa refleksyjny, smętny, niekiedy wydaje się nostalgiczny. Nie widać też rzekomej obłudy. Na pytanie, czy współodczuwał z Żydami, odpowiada z rozbrajającą prostotą, zwracając się to tłumaczki: „Przecież jak pani się skaleczy, to mnie nie boli”. Można zarzucić Borowemu skrajną nieczułość i radykalny brak współodczuwania $\mathrm{z}$ ofiarami, trudno jednak w tym momencie posądzić go o wyrachowanie czy nieszczerość.

Lanzmann nie ustaje $\mathrm{w}$ wysiłkach, ponawia pytanie o gest podrzynania: "Czy jakąś przyjemność to panu sprawiało?" [9:39], na co Borowy odpowiada: „Nie, żadną przyjemność, chciałem ich informować, że oni jadą na stracenie, żeby się bronili, żeby twardo do tego stawali. Bo pani wie [mówi do tłumaczki], jak pani powiem, że ja panią zabiję [wykonuje gest podcinania], to co pani będzie robić? No, będzie się pani bronić!".

Chwilę później Lanzmann po niemal trzydziestu minutach tej wymiany zdań, licznych podchodach, kilkunastu pytaniach o gest, sugestiach, że trzeba

11 Materiały dostępne są pod adresem: https://www.ushmm.org/online/film/search/result. php?search_type $=\&$ titles $=$ Claude + Lanzmann + Shoah + Collection $\&$ MaxPageDocs $=25 \&$ StartD OC $=1(16.02 .2017)$. 
od nowa nagrać odpowiedź, gdyż problem techniczny uniemożliwił rejestrację, osiąga efekt, który znamy z filmu: Borowy mówi raz jeszcze, że chciał ostrzegać, wykonuje gest i wybucha nerwowym śmiechem.

Z pewnością obie strony nie są niewinne i kluczą w złożonej grze, której stawką jest własny wizerunek, pamięć biograficzna i pamięć historyczna, jednak w tym konkretnym przypadku trudno pozbyć się wrażenia, że Lanzmann zachowuje się jak śledczy, który przez ustawienie i odgrywanie gestu próbuje wmówić winę rozmówcy. Mając na uwadze cały film, można stwierdzić, że początkowo marginalnie przywołany przez chłopów ruch ręki zostaje przez reżysera podchwycony i wywindowany do roli głównego gestu polskich bystanderów.

Namysł nad filmowymi ścinkami umacnia w przekonaniu, że zakłopotanie, niepewność, nerwowość chłopów - z pewnością także przez nich samych stymulowane i inscenizowane - niekoniecznie świadczą jednak o ich winie czy przyjemności wyobrażania sobie śmierci Żydów. Być może chodzi również o rozkosz samego Lanzmanna ekscytującego się przyłapywaniem chłopów na gorącym uczynku? W efekcie - jeśli faktycznie udaje się ukazać pierwotny antysemityzm Polaków - niejako „przy okazji” obnaża się Lanzmann-chłopofob.

Choć w przypadku bohaterów filmu Lanzmanna charakterystyczny ruch ręki pozostaje niejednoznaczny i niepokojący, rozpatrywany w szerszym kontekście interakcji uzmysławia nie tylko polityczny i afektywny ładunek mowy ciała, ale też potencjał nadużycia jego wizerunków. Widać teraz wyraźniej, że gest - jako emblemat, skondensowany znak - jest, jak sugeruje Jeff Wall, ,cielesną i obrazową formą świadomości historycznej"12. Pytanie jednak o czyjej świadomości i nieświadomości mowa? Wspomnijmy wybrane fragmenty z Wesela Stanisława Wyspiańskiego, gdzie Pan Młody wspomina „dziadka piłą rżniętego", czy z Pornografii Witolda Gombrowicza, gdzie zarżnięcie przez okoliczne bandy jawi się Hipolitowi jako najczarniejszy scenariusz losu w okupowanej Polsce.

Przywołane przykłady wskazują, że gest podcinania gardła - wywodzony z krwawej tradycji chłopskich samosądów i kojarzony z rzezią galicyjską staje się wtórnie obosieczną bronią, gdyż ci, którzy uważają się za potomków szlachty, ziemiaństwa i inteligencji, wykorzystują go jako metaforę nieprzekraczalnego rozdźwięku kulturowego. I nie tylko. Utożsamianie chłopów

12 J. Wall Gestus, przeł. P. Mościcki, "Widok. Teorie i praktyki kultury wizualnej” 2015 nr 12, http:// pismowidok.org/index.php/one/article/view/369/687 (24.03.2017). 
z gestem podrzynania jest insynuowaniem ich dzikości i nieprzewidywalności, fantazjowaniem o ich pasywno-zaczepności czy nieokrzesaniu i skłonności do przemocy jako immanentnej cesze ich natury. Co więcej, istotnym potencjałem jest także krytyka ekonomiczno-klasowa wpisana w ten gest. Być może jego przywoływanie bywa przejawem niejasnych wyrzutów sumienia z powodu konsekwentnego podtrzymywania i umacniania społecznych nierówności?

Słownikowe znaczenie terminu „podrzynać” oznacza „podciąć coś od spodu". Czyż nie tego właśnie boją się ci, którzy przypisują chłopom gestowy emblemat: zmiany układu sił, podcięcia dotychczasowych pozycji, wymiany społecznych ról? Jeszcze jednym pośrednim argumentem jest kontekst ponadpolski, być może także ponadeuropejski, jakim jest obecna popularność filmów przedstawiających arabskich chłopców, którzy podbiegają do kamerzystów europejskich stacji telewizyjnych tylko po to, by z uśmiechem na twarzy wykonać gest podcinania gardła. Migawkowe sceny są zresztą pieczołowicie komentowane na polskich forach jako dowód na przemocową, terrorystyczną naturę wszystkich, nawet dziecięcych migrantów ${ }^{13}$.

Paradoksalnie i polscy chłopi, i bliskowschodni chłopcy lokowani są tutaj w jednakiej pozycji radykalnej odmienności i dzikości, która ma neutralizować wyrzuty sumienia i lęki tej „lepszej”, rzekomo bardziej świadomej i kulturalnej części wspólnoty, sytuującej się w tym układzie jako niewinny obiekt agresji, jagnię, które prawie, już, za chwilę zostanie wystawione na rzeź.

Rzecz jasna ten motyw ma liczne mutacje i rozgałęzienia, historyczne i geograficzne, lokalne i globalne, tymczasem skupiam się jedynie na wybranych (mikro)przypadkach. Zakładam jednak, że nie tylko ten konkretny gest uwikłany jest w funkcjonowanie stereotypów i kulturowych klisz, które

13 Por. „Te słodkie arabskie dzieciaczki w pierwszej kolejności poderżną gardziołka paniom przedszkolankom”; " "będą im podcinać gardła, będą - zobaczą Francuzi kolejną noc św. Bartłomieja już niedługo. A później my - drugą rabację"; " "Chłopcy podrzynanie gardeł znają od dzieciństwa. Największe święto muzułmańskie Bakr-Id jest oparte na barbarzyńskiej opowieści o tym jak Abraham chciał poświęcić swego syna Izaaka Bogu (Allahowi). Aby upamiętnić to wydarzenie w ten dzień w każdym muzułmańskim kraju poświęcane są w ofierze owce i kozy a ich ubój dokonywany jest właśnie przez poderżnięcie gardła” ; "wyczuwa się stosunek ich jak do zwierzyny łownej, taka uprzejmość kota który się bawi myszą. W gruncie rzeczy są to bardzo prymitywni ludzie, najczęściej bez wykształcenia ale znaleźli słabe miejsce u nas gdzie można uderzyć naszą kulturę a przede wszystkim nasz oparty przecież na chrześcijaństwie humanizm i to wykorzystują z premedytacją". Wypowiedzi pochodzą z forów portali Wyborcza.pl, Niezależna. pl i YouTube (z komentarzy do filmów przedstawiających dzieci wykonujące gest podcinania gardła). 
mutują jego znaczenia. Z pewnością podobne emblematy są jeszcze jednym z narzędzi bogatego repertuaru nadzoru, kary, władzy i społecznej opresji, a ich oddziaływanie w niemal niezauważalny acz konsekwentny sposób umacnia podziały, rozdźwięki i napięcia, powszechnie znane jako status quo. Gest rzezania, który stanowi obosieczną broń w razie potrzeby wykorzystywaną przez różnych aktorów społecznych, choć mocny, jakoś groźny i niejednoznaczny, nie jest jedynym, który domaga się analizy.

Wiele wskazuje, że warto potraktować gesty nie tylko jako „przedłużenie" mowy, ale jako znaczące sygnały kulturowe, skondensowane znaki, przekaźniki energii, nienarracyjne sposoby wyrazu afektów i doświadczeń, niejednokrotnie także cielesne, obrazowe formy świadomości historycznej i społecznej.

Przyjmuję, że tropienie przejawów chłopskości w kulturze oraz badanie tak ogólnej i niejednoznacznej kategorii, jaką niewątpliwie jest abstrakcyjna "chłopskość, domaga się analizy uważnej, możliwie pozbawionej protekcjonalizmu i uprzedzeń, skupionej na śladach, drobnych znakach i tym, co partykularne. Proponuję zatem lekturę i obserwację wyczuloną na to, co podstawowe, wspólne i ludzkie, jednocześnie znaczące i odróżniające, a niekiedy też poróżniające: detale mowy ciała, gesty jako integralne elementy przekazu. Jednocześnie postuluję perspektywę szerszych studiów gestycznych jako jeszcze jedną próbę przełamania impasu metodologicznego i niestrudzonego pisania historii alternatywnych. 


\section{Abstract}

\section{Agnieszka Dauksza}

JAGIELLONIAN UNIVERSITY (CRACOW)

On a Certain Peasant Gesture: From the Galician Slaughter to the Shoah

The point of departure is the following research problem: who ought to analyse peasant heritage? Can narratives written from the position of an academic in the city represent the village? How can we find alternative perspectives, new methods and new descriptive tools? Dauksza focuses on two documentary films that represent Polish peasants, namely Claude Lanzmann's Shoah and Piotr Brożek's Niepamięć [Oblivion]. She proposes to think about the gesture as a significant carrier of cultural memory as well as a transmitter of social energy. She also highlights the repeatable functions of gestures. Dauksza calls studies of this type 'gesture studies'. Her main example is the gesture of throat-cutting represented in many narratives about peasants (e.g. the Galician Slaughter or the Shoah); this gesture also pervades other social contexts such as contemporary internet forums.

\section{Keywords}

gesture, gesture studies, throat-cutting, Shoah, Lanzmann, peasants 